\title{
Investigating the English Language Structural and Rhetorical Needs of Engineering Students at King Abdul-Aziz University
}

\author{
Salameh Saleem Mahmoud (Corresponding Author) \\ King Abdulaziz University/ Faculty of Engineering, Jeddah, KSA \\ Email: Nmgad2014@yahoo.com
}

Received: December 11, 2016

Accepted: January 4, 2017 Published: February 6, 2017

doi:10.5296/jet.v4i1.10426

URL: http://dx.doi.org/10.5296/jet.v4i1.10426

\begin{abstract}
This study aims at investigating the English language structural and rhetorical needs of engineering students at King Abdul-Aziz University. The instrumentation of the study is a triangulation of: a detailed analysis of the engineering students' final and most important documents (assignments, senior projects, MS theses and $\mathrm{PhD}$ dissertations) in terms of the common grammar and rhetorical mistakes, semi-structured interviews with instructors in the faculty of engineering especially those teaching (X499) (a course in which graduate students develop their senior proposals), and a questionnaire based on previous literature about engineering students' structural and rhetorical needs to be filled by engineering students taking X499. The findings of the study revealed that there are many common mistakes frequently repeated by students in their writings. These findings were confirmed by the interviews with the professors teaching 499 and the results of the questionnaire. The study concluded with a recommendation that all the common mistakes in students' documents, instructors' suggestions and the common structural and rhetorical needs resulted from the questionnaire should be included in a well- designed motivating syllabus to be taught for engineering students.
\end{abstract}

Keywords: MS, EAP, X499, Ph.D., Rhetorical categories, Grammatical Structures

\section{Introduction}

In this age of globalization, communication in English for engineers whose native language is not English is as important as their major related abilities. In Saudi Arabia as well as other Gulf states, competency in English language especially for engineers has assumed a unique interest because of these reasons: Firstly, most of the big cities in KSA are now cosmopolitan and most of the big contracting companies working in constructions are not Saudis, in addition to the fact that university instruction in KSA is entirely in the English language. Secondly, most of the professors teaching in the faculty of engineering are non-Saudis or 
probably non-Arabs. Thirdly, most of the publications in engineering field are in English. All the reasons above make engineers whose native language is not English find disadvantages in their professional terms. This situation creates an urgent demand that Saudi engineers must be competent in at least one language other than Arabic, a language that people all over the world can understand. That universal language which almost every educated person can get by is English. The documents (assignments, MS theses and $\mathrm{PhD}$ dissertations) engineering students prepare should be written in structurally correct English to be kept in the university archives for later exploitation. The current study was done to address these needs to help students write in relatively good English.

\section{Review of Literature}

Despite the fact that commonsense and educational sense imply that needs analysis and functional analysis are unavoidable steps for any syllabus design, educators and curriculum designers still prepare syllabuses and curricula without even consulting the clients. Kittidhaworn (2001) designed a two-part self-assessment questionnaire to investigate the English-language needs of 182 second-year Thai undergraduate engineering students. The findings of this study indicate that the majority of these engineering students seem to show similarity with their perceived English-language needs in those four major areas listed in the questionnaire as being moderately important or very important to learn in their second year English program in engineering. Rayan (2007) cited in Sasidharan (2012) emphasized the importance of involving ESP learners in designing their courses as this may improve their interest and motivation, promote critical thinking and increase their enthusiasm while doing activities. This hopefully results in enjoyment and better achievement of course objectives. Observing the workplace (companies, factories, workshops and projects sites and the past students working there is another idea suggested by (Hussein, 2013). Such observation will certainly help the course designer while designing the course materials in the future.

Results of research on what to include in ESP courses for engineers vary according to the target clients and reasons of studies. Salehi (2010) conducted a study to address three issues: to evaluate students' needs, to evaluate the psychometric qualities of the developed questionnaire, and to explore the possibility of writing a textbook based on the insights gained from the study. His findings showed that translation was not considered appropriate and note taking was not seen as important in their future careers, but technical writing which has been totally ignored in the English curriculum in the university was considered very important. Atai and Shoja (2011) aimed at assessing the present and target situation of academic language needs of undergraduate students of computer engineering. Despite some inconsistencies in participants' perceptions of target situation needs, the findings showed that: writing skills and language components are important, the undergraduates have difficulties with some sub-skills. The General English Proficiency test, self -assessment results and teacher assessment data indicated low achievement for the participants. The undergraduates held that they need not only highly specific academic English, but also general English. Sasidharan (2012) conducted a study to assess the English language needs of learners of engineering colleges of Orissa and to study how effectively they have been implemented at the classroom level. It also attempted to find out how language skills along with life-skills can be learnt 
effectively by engineering students for proper utilization in real life situations. Based on the study, the findings were the following: The goals and objectives of the present syllabus are only being partially fulfilled. There is deficient acquisition of English language skills among students for proper application in the workplace context and also in real- life situations. Teachers are not getting adequate training in the latest language teaching methods so that effective classroom teaching becomes a norm rather than an exception. Based on the findings of the study it is recommended that learners be involved more in interactive sessions in classrooms so that they are able to strengthen their communicative competence. Additionally, teaching technical and business communication and technology assisted language learning are areas that should be taken up on a priority basis while learning English for engineering purposes. Kim, (2013) aimed at providing detailed description of the needs analysis to develop an ESP course for engineering students in Korea.

\subsection{Students' Attitudes towards English}

A positive enthusiastic attitude towards learning English is an unavoidable condition in such an age of information explosion. Al-Tamimi ((2009) outlined the results of a survey which was carried out to identify Petroleum Engineering students' motivation and attitudes towards learning the English language. The study investigated students' motivation in terms of three motivational constructs: instrumental motivation, integrative motivation and personal motivation based on Gardner's (1985) and Cooper and Fishman's (1977) works. Learners' attitudes, on the other hand, regarding 1) the use of English in the Yemeni social context, 2) the use of English in the Yemeni educational context, 3) the English language and 4) the culture of the English speaking world were identified. The findings showed the subjects' greater support of instrumental reasons for learning the English language including utilitarian and academic reasons. Personal reasons were also regarded as important motives by the students. However, regarding the integrative reasons, the results provided evidence that learning English as a part of the culture of its people had the least impact in students' English language motivation. On the other hand, data for the students' attitudes revealed that most of students had positive attitudes towards the social value and educational status of English. In addition, the findings showed the students' positive orientation toward the English language. Interestingly, the results indicated that a high number of the students showed their interest in the culture of the English speaking world as represented by English-language films.

\section{Methodology}

\subsection{Participants}

The participants included $23 \mathrm{KAU}$ students belonging to eight departments in the faculty of engineering: mechanical engineering, industrial engineering, electrical engineering, civil engineering, computer engineering, aerospace engineering, chemical \& materials engineering and nuclear engineering. These students are taking X499 as a requirement for BSc in the above mentioned departments. The other group of participants is eight professors supervising the students in their projects and assignments. 


\subsection{Instrumentation}

The instruments used in the current study were: a questionnaire consisting of two parts: the first part is personal information about the respondents and the second part deals with structural and rhetorical needs of engineering students. In order to insure understandability on the part of the participants, an Arabic version of the questionnaire was administered. The second instrument is a semi structured interview with the professors about their perceptions of the English language needs of the students they are supervising. The third instrument is an analysis of the students' proposals, assignments and MS theses in terms of structural and rhetorical mistakes.

\subsection{Data collection}

The data were collected while students were taking their final exams. The timing was deemed appropriate on the grounds that there was the maximum number of students and odds were slim for any questionnaires not to be returned.

\section{The Results of the Study}

\subsection{Results related to analyzing students' documents}

Table (1) shows the common mistakes in thirty documents (senior projects, MS theses and assignments) written by students in the Faculty of Engineering.

\begin{tabular}{|c|c|c|c|c|}
\hline $\begin{array}{l}\text { No } \\
\#\end{array}$ & Type of Mistake & Frequency & Examples of mistakes & The correct form \\
\hline \multirow[t]{3}{*}{1} & \multirow[t]{3}{*}{ Spelling } & \multirow{3}{*}{$\begin{array}{l}\text { Plenty when } \\
\text { students write. }\end{array}$} & Mean, & Main, \\
\hline & & & Deference & Difference \\
\hline & & & Statistiks & Statistics \\
\hline \multirow[t]{3}{*}{2} & \multirow{3}{*}{$\begin{array}{l}\text { Voice- using passive/ } \\
\text { active wrongly }\end{array}$} & \multirow[t]{3}{*}{35} & it can define as follows & It can be defined as follows \\
\hline & & & maintained easily & can be maintained easily \\
\hline & & & $\begin{array}{l}\text { what we have taught in } \\
\text { engineering }\end{array}$ & $\begin{array}{l}\text { what we have been taught in } \\
\text { engineering }\end{array}$ \\
\hline \multirow[t]{3}{*}{3} & \multirow[t]{3}{*}{$\begin{array}{l}\text { Misuse of } \\
\text { prepositions }\end{array}$} & \multirow[t]{3}{*}{22} & $\begin{array}{l}\text { Was fixed away of the fast } \\
\text { winds }\end{array}$ & $\begin{array}{l}\text { Was fixed away from the fast } \\
\text { winds }\end{array}$ \\
\hline & & & $\begin{array}{l}\text { The AC motor consists by } \\
\text { two parts }\end{array}$ & $\begin{array}{l}\text { The AC motor consists of two } \\
\text { parts }\end{array}$ \\
\hline & & & They associate to ..... & They associate with... \\
\hline \multirow[t]{3}{*}{4} & \multirow{3}{*}{$\begin{array}{l}\text { Misuse of the present } \\
\text { participle }\end{array}$} & \multirow[t]{3}{*}{27} & by specify & By specifying \\
\hline & & & after test the simulation & After testing the simulation \\
\hline & & & $\begin{array}{l}\text { help in increase the } \\
\text { manufacture }\end{array}$ & $\begin{array}{l}\text { Help in increasing the } \\
\text { manufacture }\end{array}$ \\
\hline \multirow[t]{3}{*}{5} & \multirow[t]{3}{*}{ Articles } & \multirow[t]{3}{*}{42} & Change to square wave & Change to a square wave \\
\hline & & & for human body & For the human body \\
\hline & & & we are on right track & We are on the right track \\
\hline
\end{tabular}




\begin{tabular}{|c|c|c|c|c|}
\hline \multirow[t]{3}{*}{6} & \multirow[t]{3}{*}{ Relative clauses } & \multirow[t]{3}{*}{16} & $\begin{array}{l}\text { Which the brown and blue are } \\
\text { operating... }\end{array}$ & $\begin{array}{l}\text { Where the brown and blue are } \\
\text { operating }\end{array}$ \\
\hline & & & $\begin{array}{l}\text { And the paper to the } \\
\text { minimum range when it } \\
\text { should give the supply.. }\end{array}$ & $\begin{array}{l}\text { And the paper to the } \\
\text { minimum range where it } \\
\text { should give the supply.. }\end{array}$ \\
\hline & & & Give it to who you meat & Give it to whom you meat \\
\hline \multirow[t]{3}{*}{7} & \multirow[t]{3}{*}{ Word order } & \multirow[t]{3}{*}{13} & $\begin{array}{l}\text { The Arduino board usually is } \\
\text { used }\end{array}$ & $\begin{array}{l}\text { The Arduino board is usually } \\
\text { used }\end{array}$ \\
\hline & & & As what said before & $\begin{array}{l}\text { According to what had been } \\
\text { said before }\end{array}$ \\
\hline & & & $\begin{array}{l}\text { The provided problems from } \\
\text { the customer }\end{array}$ & $\begin{array}{l}\text { The problems provided from } \\
\text { the customers. }\end{array}$ \\
\hline \multirow[t]{3}{*}{8} & \multirow[t]{3}{*}{ Tense } & \multirow[t]{3}{*}{32} & To producing & To produce \\
\hline & & & The stator having coils ... & The stator has coils ... \\
\hline & & & I am work.... & I am working. \\
\hline \multirow[t]{3}{*}{9} & \multirow[t]{3}{*}{$\begin{array}{l}\text { Misuse of linking } \\
\text { words }\end{array}$} & \multirow[t]{3}{*}{17} & $\begin{array}{l}\text { We took the measures, we } \\
\text { change the materials... }\end{array}$ & $\begin{array}{l}\text { We took the measures, then } \\
\text { we change the materials. }\end{array}$ \\
\hline & & & Societies which their codes & Societies whose codes \\
\hline & & & $\begin{array}{l}\text { Engineers whom are in } \\
\text { Islamic environments }\end{array}$ & $\begin{array}{l}\text { Engineers in Islamic } \\
\text { environments }\end{array}$ \\
\hline \multirow[t]{3}{*}{10} & \multirow{3}{*}{$\begin{array}{l}\text { Subject verb } \\
\text { agreement }\end{array}$} & \multirow[t]{3}{*}{37} & The solver team come.. & The solver team comes. \\
\hline & & & Numbers doesn't fit.. & Numbers don't fit \\
\hline & & & $\begin{array}{l}\text { The measures has great } \\
\text { effect .... }\end{array}$ & $\begin{array}{l}\text { The measures have great } \\
\text { effect }\end{array}$ \\
\hline \multirow[t]{3}{*}{11} & \multirow[t]{3}{*}{$\begin{array}{l}\text { Short form of relative } \\
\text { clauses }\end{array}$} & \multirow[t]{3}{*}{11} & $\begin{array}{l}\text { The team who is associated, } \\
\text { every person whom involved, }\end{array}$ & $\begin{array}{l}\text { The team associated., every } \\
\text { person involved, }\end{array}$ \\
\hline & & & important issues that related & Important issues related \\
\hline & & & $\begin{array}{l}\text { those that having a high } \\
\text { interest }\end{array}$ & those having a high interest, \\
\hline \multirow[t]{3}{*}{12} & \multirow[t]{3}{*}{ Tense consistency } & \multirow[t]{3}{*}{19} & $\begin{array}{l}\text { The government is having a } \\
\text { high power, }\end{array}$ & $\begin{array}{l}\text { The government has a high } \\
\text { power, }\end{array}$ \\
\hline & & & The results was presented & The results showed \\
\hline & & & They found and decide.. & They found and decided. \\
\hline \multirow[t]{3}{*}{13} & \multirow[t]{3}{*}{ Possessive } & \multirow[t]{3}{*}{9} & $\begin{array}{l}\text { To take into their } \\
\text { consideration }\end{array}$ & To take into consideration \\
\hline & & & $\begin{array}{l}\text { The university is having high } \\
\text { power }\end{array}$ & $\begin{array}{l}\text { The university has high } \\
\text { power }\end{array}$ \\
\hline & & & The participants responses & The participants' responses \\
\hline \multirow[t]{3}{*}{14} & \multirow[t]{3}{*}{ Parallel structure } & \multirow[t]{3}{*}{22} & $\begin{array}{l}\text { Dangerous to have and } \\
\text { poison, }\end{array}$ & $\begin{array}{l}\text { Dangerous to have and } \\
\text { poisonous, }\end{array}$ \\
\hline & & & We derived and show & We derived and showed \\
\hline & & & by going and apply.... & by going and applying \\
\hline
\end{tabular}




\begin{tabular}{|c|c|c|c|c|}
\hline \multirow[t]{3}{*}{15} & \multirow[t]{3}{*}{ Pronouns } & \multirow[t]{3}{*}{12} & Each person whom associated & Each person associated \\
\hline & & & In the other hand & On the other hand \\
\hline & & & Stage after stage & Stage by stage \\
\hline \multirow[t]{3}{*}{16} & \multirow[t]{3}{*}{ Demonstratives } & \multirow[t]{3}{*}{14} & They investigated these effect & They investigated this effect \\
\hline & & & This results are not clear... & These results are not clear... \\
\hline & & & That people were involved & Those people were involved \\
\hline \multirow[t]{3}{*}{17} & \multirow[t]{3}{*}{ Parts of speech } & \multirow[t]{3}{*}{25} & $\begin{array}{l}\text { Providing final approve of the } \\
\text { project, }\end{array}$ & $\begin{array}{l}\text { Providing final approval of } \\
\text { the effect. }\end{array}$ \\
\hline & & & $\begin{array}{l}\text { shows the different in } \\
\text { intensity }\end{array}$ & $\begin{array}{l}\text { Shows the difference in } \\
\text { intensity }\end{array}$ \\
\hline & & & they were success, & They were successful \\
\hline \multirow[t]{3}{*}{18} & \multirow[t]{3}{*}{ Modals } & \multirow[t]{3}{*}{16} & The government will takes, & The government will take, \\
\hline & & & He might left the door open & $\begin{array}{l}\text { He might have left the door } \\
\text { open }\end{array}$ \\
\hline & & & $\begin{array}{l}\text { They has to finish the work } \\
\text { on time }\end{array}$ & $\begin{array}{l}\text { They have to finish the work } \\
\text { on time }\end{array}$ \\
\hline \multirow[t]{3}{*}{19} & \multirow[t]{3}{*}{ Choice of words } & \multirow[t]{3}{*}{9} & $\begin{array}{l}\text { For five continues days, at the } \\
\text { first, }\end{array}$ & $\begin{array}{l}\text { For five successive days, at } \\
\text { the beginning, }\end{array}$ \\
\hline & & & Grateful thanks & Many thanks \\
\hline & & & Is exposed for high doses & Is exposed to high doses \\
\hline \multirow[t]{3}{*}{20} & \multirow[t]{3}{*}{ Word missing } & \multirow[t]{3}{*}{15} & $\begin{array}{l}\text { The stakeholders clearly } \\
\text { identified, }\end{array}$ & $\begin{array}{l}\text { The stakeholders are clearly } \\
\text { identified, }\end{array}$ \\
\hline & & & Which generated & Which is generated \\
\hline & & & $\begin{array}{l}\text { In work, show the variation } \\
\text { dose... }\end{array}$ & $\begin{array}{l}\text { In our work, we will show the } \\
\text { variation.. }\end{array}$ \\
\hline \multirow[t]{3}{*}{21} & \multirow[t]{3}{*}{ Unnecessary words } & \multirow[t]{3}{*}{21} & $\begin{array}{l}\text { Make them to change their } \\
\text { minds. }\end{array}$ & $\begin{array}{l}\text { Make them change their } \\
\text { mind. }\end{array}$ \\
\hline & & & Go to home & Go home \\
\hline & & & They gave to me the job & They gave me the job \\
\hline
\end{tabular}

\subsection{Results of the Interview}

The respondents to the interviews were mostly professors in mechanical engineering, civil engineering, nuclear engineering, electrical engineering, aeronautical engineering, chemical engineering and the Academic Language Support Unit (ALSU). They were interviewed separately about their opinions about students' weakness in certain aspects of English language and how these weaknesses can be treated. When asked whether they are happy about the level of students in their structural and rhetorical skills, they agreed unanimously that 499 students have a real problem that appears clearly in their writing and speaking tasks. They confuse tenses, use prepositions wrongly, miss out the verb to be, don't use linking words or transitional expressions, misuse relative clauses and leave out the verb to be in passive constructions. Dr. Fuad, Dr. Rami, Dr. Amro and Dr. Majdi said that this weakness 
refers back to schools where students used to start learning English at the age of 10. It is also a result of carelessness on the part of teachers and students who were not taking teaching English seriously. In addition to the poor weight of English language classes compared to other courses in the students' schedules. All of the respondents agreed that a course that deals with the common mistakes engineering students usually make while writing their tasks can be delivered to students among the other general topics students usually take in their first year in the faculty of engineering. They all pointed out that a document nearly free of mistakes is a must as it will be kept in the faculty archives for other students to use later.

\subsection{Results related to the questionnaire}

Table (2) shows the results of part two of the questionnaire in terms of the percentages of the four- Likert scale - very important, moderately important, slightly important and not important.

\begin{tabular}{|c|c|c|c|c|c|}
\hline $\begin{array}{l}\text { No. } \\
\#\end{array}$ & & $\begin{array}{l}\text { Very } \\
\text { important }\end{array}$ & $\begin{array}{l}\text { Moderately } \\
\text { Important }\end{array}$ & $\begin{array}{l}\text { Slightly } \\
\text { important }\end{array}$ & $\begin{array}{l}\text { Not } \\
\text { Important }\end{array}$ \\
\hline \multicolumn{6}{|c|}{ Language Structures } \\
\hline 1 & $\begin{array}{l}\text { Word structures (compounding, affixation, } \\
\text { nominalization) }\end{array}$ & $40.9 \%$ & $59.1 \%$ & $0 \%$ & $0 \%$ \\
\hline 2 & $\begin{array}{l}\text { Grammatical structures frequently used in } \\
\text { scientific discourse ((For example: present } \\
\text { participles, passives, conditionals, etc. }\end{array}$ & $63.6 \%$ & $27.3 \%$ & $9.1 \%$ & $0 \%$ \\
\hline 3 & $\begin{array}{l}\text { Grammatical structures for general } \\
\text { communications (tenses, aspects, modality, } \\
\text { etc.) }\end{array}$ & $86.4 \%$ & $13.6 \%$ & $0 \%$ & $0 \%$ \\
\hline 4 & $\begin{array}{l}\text { Signaling syntactic boundaries using } \\
\text { punctuation marks ((For example: comma, } \\
\text { colon, semicolon, dash, etc.) }\end{array}$ & $45.5 \%$ & $50 \%$ & $4.5 \%$ & $0 \%$ \\
\hline 5 & Subject/ verb agreement & $90.9 \%$ & $5 \%$ & $4.1 \%$ & $0 \%$ \\
\hline 6 & Word order & $90.9 \%$ & $4.5 \%$ & $4.5 \%$ & $0 \%$ \\
\hline 7 & Parts of speech & $59.1 \%$ & $40.9 \%$ & $0 \%$ & $0 \%$ \\
\hline \multicolumn{6}{|c|}{ Rhetorical Categories } \\
\hline 8 & $\begin{array}{l}\text { Logical connectors used to link clauses and } \\
\text { sentences (For example: therefore, hence, } \\
\text { consequently, as a result, etc.) }\end{array}$ & $50 \%$ & $50 \%$ & $0 \%$ & $0 \%$ \\
\hline 9 & $\begin{array}{l}\text { Classification } \\
\text { (For example: consist of, is divided into, is } \\
\text { composed of, etc...) }\end{array}$ & $36.4 \%$ & $45.5 \%$ & $18.2 \%$ & $0 \%$ \\
\hline 10 & $\begin{array}{l}\text { Definition } \\
\text { (For example: is known as, is called, } \\
\text { mean,....) }\end{array}$ & $54.5 \%$ & $36.4 \%$ & $9.1 \%$ & $0 \%$ \\
\hline 11 & $\begin{array}{l}\text { Exemplification } \\
\text { (For example: such as, like, e.g., for instance, }\end{array}$ & $63.6 \%$ & $31.8 \%$ & $4.5 \%$ & $0 \%$ \\
\hline
\end{tabular}




\begin{tabular}{|l|l|l|l|l|l|}
\hline & etc. & & & & \\
\hline 12 & $\begin{array}{l}\text { Generalization } \\
\text { (For example: in other words, in short, in } \\
\text { conclusion, etc...) }\end{array}$ & $54.5 \%$ & $27.3 \%$ & $18.2 \%$ & $0 \%$ \\
\hline 13 & $\begin{array}{l}\text { Chronological sequence } \\
\text { (For example: at first, then, next, } \\
\text { afterwards, ultimately, etc ...) }\end{array}$ & $59.1 \%$ & $31.8 \%$ & $9.1 \%$ & $0 \%$ \\
\hline 14 & $\begin{array}{l}\text { Articles and quantifiers ( the, an, the, some, } \\
\text { any, few, a few, ........etc. }\end{array}$ & $47.6 \%$ & $28.6 \%$ & $19 \%$ & $4.8 \%$ \\
\hline
\end{tabular}

The students' responses to Part One of the questionnaire which deals with personal information about the respondents were as follows: $66.7 \%$ of the respondents were students in the Industrial Engineering Department. The rest are distributed to Chemical engineering (14.3\%), Electrical Engineering (9.5\%) and nearly $10 \%$ is shared by mechanical, computer and civil engineering. About the number of years they studied English at schools, more than $50 \%$ of the respondents studied English between 8 and 12 years. The level of the respondents in the four skills was 85 to $90 \%$ good or moderate except for reading where respondents were $50 \%$ good or moderate.

As shown in table (2) above the students' responses to part two of the questionnaire which deals with language structures and rhetorical categories were as follows: All the respondents agreed that compounding, affixation and nominalization are either very important or moderately important. The present participle, the passive voice and conditional sentences were nearly 90\% important. Tenses, aspect, modality, punctuation marks, subject/verb agreement and parts of speech were considered 100\% important. Rhetorical categories were also deemed important by respondents. Logical connectors were $50 \%$ very important and $50 \%$ moderately important. Classification devices and generalization were considered nearly $80 \%$ important and $18.2 \%$ considered it slightly important. Nearly $90 \%$ considered the definition, exemplification and chronological sequence tools as very important and moderately important. Finally, respondents considered articles and quantifiers as $47.6 \%$ very important, $28.6 \%$ as moderately important and $19 \%$ as slightly important.

\section{Discussion}

As table (1) shows, students in the faculty of engineering have committed many mistakes while writing their documents. What is included in the table are only the common mistakes, the frequency of the mistakes and three examples for each. This number of mistakes is too high for university students whose level of English should be better. The unsatisfactory level of English for the target students may refer to the lack of attention on the part of teachers and the absence of interest and motivation on the part of students at school. The foundation year was not enough to bridge the gap and to cope with this weakness. The confirmation from the professors in the faculty of engineering is enough proof that the problem is alarming and something should be done before it is too late. "The assignments, the senior projects and even the first drafts of MSs are most of the time unreadable”, (Dr. Fuad from Mechanical 
Engineering, 25 th Nov., 2016.) "We could easily discover where students are copying when the text is free of mistakes", (Dr. Rami, 12 $2^{\text {th }}$ Nov., 2016.) "It sometimes takes me one hour to make one page readable” DR. Mamoon from the Academic Language Support Unit, ${ }^{\text {rd }}$ Dec. 2016). In their answers to the interview questions, they all agreed that something should be done urgently to help students write in a better way. They also emphasized the fact that engineers should write in good English as technical writing for them is a life function as well as an academic function.

The results of the questionnaire are motivating to curriculum designers as they show the students' feeling of responsibility exemplified by their responses which were nearly limited to very important, moderately important and slightly important in rare cases. This shows that they feel there is a real problem in their writing especially in the areas mentioned in the questionnaire. This agrees with other studies done in nearly the same environments and similar measures were taken by decision makers, (Kittidhaworn, 2001; Salehi, 2010 and Sasadhiran, 2012). These measures came as needs analyses for students' documents, classroom observations and interviews with instructors and questionnaires, (Kittidhworn, 2001; Ataie \& Shoja, 2011).

The needs analysis is done and the target is very clear. The language structures and the rhetorical categories are the backbone of a syllabus that needs flesh and blood. The flesh and blood are the motivating reading comprehension texts, the appealing activities, the tasks related to students field of study and finally the context that lends itself to critical thinking and problem solving. On the other hand, the implementation should echo the motivating contexts. The teaching strategies should involve students in activities and use the multimedia that is appealing to students. Well-structured cooperative group work in teaching grammar is an idea suggested by (Athmani, 2010).

\section{Conclusion}

It is apparent from the survey of students' documents, the interview with the professors in the faculty of engineering and from the students' responses to the questionnaire that there is a big problem related to writing in general and technical writing in particular. This situation calls for urgent remedial work that may be a technical writing course given to students somewhere in their plan and the common mistakes in the survey and the questionnaire could be the backbone of such a course. It can also be creating a specialized unit in the faculty of engineering that assumes the responsibility of training students, editing their work and giving them feedback and changing the common mistakes into workshops given to students at intervals. Individual feedback is also essential. One to one interaction helps in consciousness raising of mistakes. An awareness creation sets the learner thinking and makes corrections on his own. The remediation provided should be contextual, meaningful and appropriate. A combination of communicative exercises along with relevant grammar rules in a contextualized manner makes students feel that these grammar rules are really needed for successful communication whether in speech or in writing. 


\section{Acknowledgement}

I would like to convey my gratitude to the dean of the faculty of engineering who allowed me to conduct my research and made my job easy. I would like also to thank the interviewees and the respondents (the students in the faculty of engineering) who were very cooperative and helpful. Finally, my deep gratitude is conveyed to my family who were very patient and helpful to me.

\section{References}

Al-Tamimi, A., \& Shuib, M. (2009). Motivation and attitudes towards learning English: A study of petroleum engineering undergraduates at Hadhramout University of Sciences and Technology. GEMA: Online Journal of Language Studies, 9(2), 29-55.

Atai, M. R., \& Shoja, L. (2011). A triangulated study of academic language needs of Iranian students of computer engineering: are the courses on track?. RELC Journal, 42(3), 305-323.

Athmani, A. (2010). Motivating Students to Learn Grammar through the Cooperative Learning Techniques. The case of $2^{\text {nd }}$ year English students at the University of Constantine. $M A$ Dissertation. 2009-2010, University of Constantine/ Algeria.

Hossain, M. (2013). ESP needs analysis for engineering students: A learner centered approach. Presidency University, 2(2), 16-26.

Kim, H. H. (2013). Needs analysis for English for specific purpose course development for engineering students in Korea. International Journal of Multimedia and Ubiquitous

Engineering, 8(6), 279-288.

Kittidhaworn, P. (2001). An Assessment of the English-Language Needs of Second-Year Thai Undergraduate Engineering Students in a Thai Public University in Thailand in Relation to the Second-Year EAP Program in Engineering. PhD Dissertation, West Virginia University, Morgantown, West Virginia.

Salehi, M. (2010). Investigating the English language needs of engineering students. English for Specific Purposes World, 10(31), 1-16.

Sasidharan, P. (2012). A Needs Based Approach to Teaching and Learning of English for Engineering Purposes (Doctoral dissertation).

\section{Appendixes}

Appendix (1) Students' Questionnaire

Student Questionnaire Instructions:

This questionnaire is composed of two parts:

Part A is about yourself.

Part B consists of 14 items to elicit your language structural and rhetorical needs. These items cover the specific purposes for the present and future academic needs in the study of English 


\section{Macrothink

for Engineering. Before responding to this Students' questionnaire, you are required to consider each item carefully based on your own needs and then indicate how important each of these items is for your study in your English for engineering course.

For each item in the questionnaire, please check $(\checkmark)$ in only one box under the four levels of importance from Very Important to Not Important to indicate how important each item is to you, as shown in the following example below:

$$
\begin{aligned}
& \text { بسم الله الرحمن الرحيم } \\
& \text { عزيزي الطالب, تهدف هذه الأستبانه الى معرفة حاجات طلاب كلية الهندسة من حيث التر اكيب اللغوية والتي تعتبر من }
\end{aligned}
$$

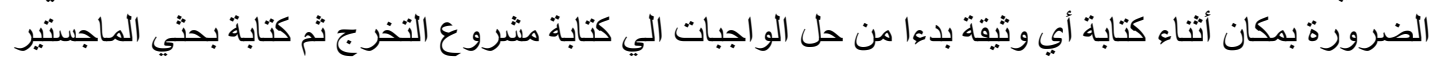

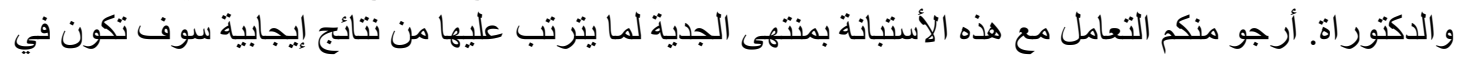

$$
\begin{aligned}
& \text { مصلحتكم إنشاء الله. }
\end{aligned}
$$

Examples:

Your experience in learning English outside the classroom situations

يتعلق هذا المثال بخبرتكم في تعلم اللغة الأنجليزية خار ج غرفة الصف.

\begin{tabular}{|l|l|l|l|l|}
\hline & Very important & $\begin{array}{l}\text { Moderately } \\
\text { Important }\end{array}$ & $\begin{array}{l}\text { Slightly } \\
\text { Important }\end{array}$ & Not Important \\
\hline Reading a newspaper in English & & & & $\sqrt{ }$ \\
\hline Watching films & & $\sqrt{ }$ & & \\
\hline $\begin{array}{l}\text { Talking to native speakers of } \\
\text { English }\end{array}$ & $\sqrt{ }$ & & & \\
\hline
\end{tabular}

Part A: الجزء الأول من الأستبانة يتعلق بالمعلومات الثخصبة عن الطالب.

1. Your specific field of Engineering. ما هو تخصصك في كلية الهندسة

$\square$ Chemical Engineering

$\square \quad$ Civil Engineering

$\square \quad$ Computer Engineering

$\square \quad$ Electrical Engineering

$\square \quad$ Industrial Engineering

$\square \quad$ Mechanical Engineering 
2. Number of years that you studied English in the school(s) عدد سنوات دراسة اللغة الأنجليزية في كلية الهندسة
$\square 12$
$\square 11$
$\square 10$
$\square 9$
$\square 8$
$\square 7$
$\square 6$
$\square 5$

$\square$ Other:

3. Please indicate your English-language-skill level ما هو مستو الك في مهار ات اللغة الأنجليزية الأربع?

\begin{tabular}{|c|c|c|c|c|}
\hline & Good & Moderate & Poor & Very Poor \\
\hline 3.1. Listening & $\square$ & $\square$ & $\square$ & $\square$ \\
\hline 3.2. Speaking & $\square$ & $\square$ & $\square$ & $\square$ \\
\hline 3.3. Reading & $\square$ & $\square$ & $\square$ & $\square$ \\
\hline 3.4. Writing & $\square$ & $\square$ & $\square$ & $\square$ \\
\hline
\end{tabular}

\section{PART B.}

Please indicate how important the following items are for your study in this English course in relation to language structure. Please check $(\checkmark \quad)$ in only one box for each item under the four levels of importance (from Very Important to Not Important) that you have selected.

$$
\text { من فضلك أنر الى أهمية الأشياء التالية لدر استك لهذا المساق في ما يتعلق بالتر اكيب اللغوية }
$$

1. Language Structures التر اكيب اللغوية

\begin{tabular}{|c|c|c|c|c|c|}
\hline No \# & Item & Very Important & $\begin{array}{l}\text { Moderately } \\
\text { Important }\end{array}$ & $\begin{array}{l}\text { Slightly } \\
\text { Important }\end{array}$ & Not Important \\
\hline \multicolumn{6}{|c|}{ Language Structures } \\
\hline 1 & $\begin{array}{l}\text { Word structures } \\
\text { (compounding, } \\
\text { affixation, } \\
\text { nominalization) المقاطفير قلمبل وبعد الكلمات } \\
\text { المعنى أو أقسام الكلام }\end{array}$ & & & & \\
\hline 2 & $\begin{array}{l}\text { Grammatical structures } \\
\text { frequently used in } \\
\text { scientific discourse } \\
\text { ((For example: present }\end{array}$ & & & & \\
\hline
\end{tabular}




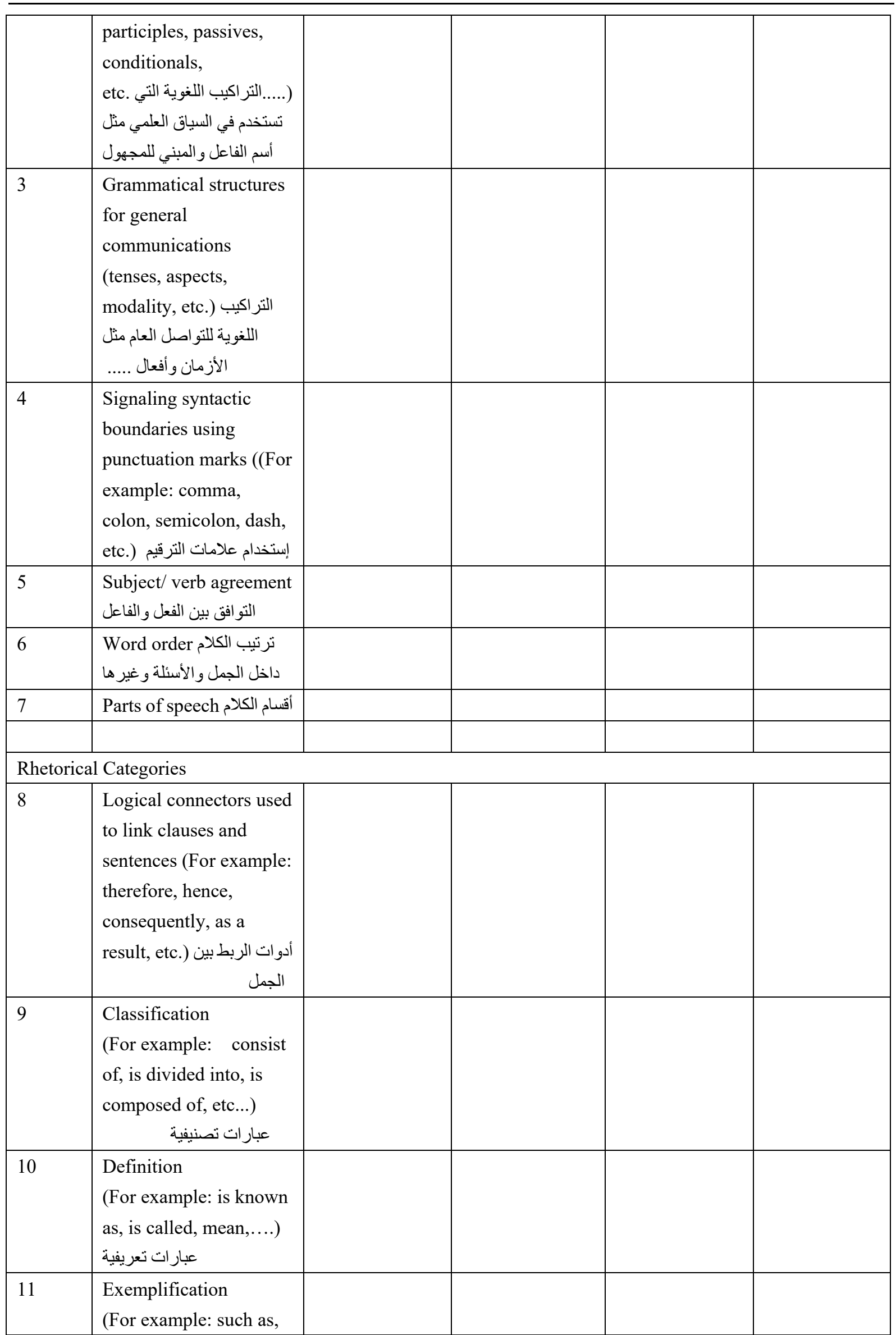




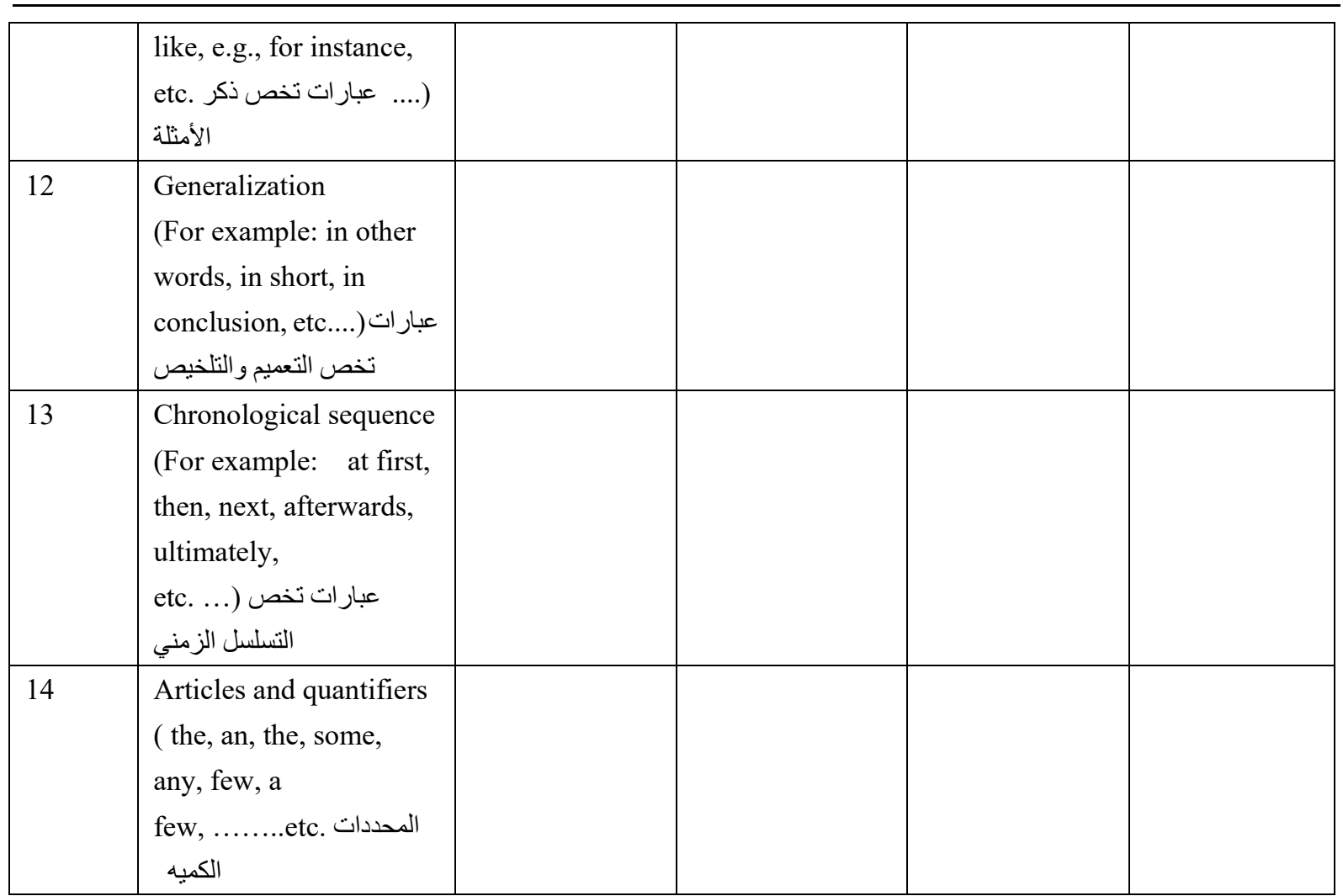

\section{Appendix (2) Interview Questions}

This interview is meant for the professors who teach (X499) a course dedicated to help last year students develop their research proposals

Interview questions

1. Are you happy with the structural and rhetorical level of the students in X499?

2. If not, what structural and rhetorical skills are missing?

3. In your opinion, why do you think these skills are missing?

4. What do you think the solutions are?

5. Is it important for an engineer to write in almost perfect English? Why?

\section{Copyright Disclaimer}

Copyright reserved by the author(s).

This article is an open-access article distributed under the terms and conditions of the Creative Commons Attribution license (http://creativecommons.org/licenses/by/3.0/). 